\title{
Evaluation of improved hermaphrodite papaya (Carica papaya L.) varieties at Arba Minch, Southern Ethiopia
}

\author{
G. Fikre*iD and A. Mensa \\ Received 15 July 2021, Revised 28 October 2021, Accepted 20 December 2021, Published online 31 December 2021
}

\begin{abstract}
A B S T R A C T
The experiment was conducted to evaluate the adaptability of newly released papaya varieties at Chano Mille research site of Arba Minch Agricultural Research Center during 2019-2020 cropping seasons. The three hermaphrodite papaya varieties namely; Braz-HS1, Koka-HM1 and Meki-HL1 were used for the study and laid-out in a Randomized Complete Block Design in three replications. Data on yield and yield components were collected and analyzed by using analysis of variance (ANOVA) through Statistical Analytics System software. The ANOVA results revealed that there were significant variations among papaya varieties for the studied parameters. Significantly, the highest number of fruits plant ${ }^{-1}$, number of leaves and fruit yield were obtained from Braz-HS1 papaya variety. The fruit yield of Braz-HS1 variety was $46 \%$ higher than that of Koka-HM1. In general, Braz-HS1 papaya variety performed (in terms of number of fruits and fruit yield) better than the rest two varieties. Thus, Braz-HS1 papaya variety could be recommended for the papaya growers in the study area and vicinity with similar agro-ecology.
\end{abstract}

Keywords: Adaptability, Arba Minch, Fruit yield, Papaya varieties

Fruit and Vegetable Crops Breeding Division, Arba Minch Agricultural Research Center, Southern Agricultural Research Institute, P.O. Box 2228, Ethiopia

*Corresponding author’s email: fikregezahegn@gmail.com (G. Fikre)

Cite this article as: Fikre, G. and Mensa, A. 2021. Evaluation of improved hermaphrodite papaya (Carica papaya L.) varieties at Arba Minch, Southern Ethiopia. Int. J. Agril. Res. Innov. Tech. 11(2): 69-71. https://doi.org/10.3329/ijarit.v11i2.57257

\section{Introduction}

Papaya (Carica papaya L.) is a short-lived perennial plant in the genus Carica under the family of Caricaceae. It is among the most important fruit crops growing mainly in the tropical and warmest parts of subtropical regions of the world. Papaya fruits are very popular due to their high nutritive, medicinal and other multiple uses such as meat tenderizer (extracted papain), raw materials for cosmetics, soft drinks and food canning industries and it is one of the high value fruit crops (Munoz et al., 2000; Josef, 2008; Mello et al., 2008; Ming et al., 2008; Serrano and Cattaneo, 2010). Moreover, papaya helps the human body to properly digest food and important to control premature aging (Sepiah, 1993; Milind and Gurditta, 2017).

In Ethiopia, papaya is one of the most important fruit crops, which is produced for fresh and processed local consumption as well as for fresh fruit export purpose. Like for other fruits, the demand for papaya is increasing steadily due to rapid population growth and changes in dietary habits, but its productions have not been expanded as the country's potential and market demand. In recent years, it has also attained great popularity primarily because of its easy cultivation, quick returns (early fruiting as compared to other fruit crops), adaptability to diverse soil and climatic conditions; it occupies significant positions in homestead, smallholder and commercial production for home consumption and income generation.

Currently, papaya covered about 4010 hectares of land with total production of 59,205 tons in Ethiopia during 2018-2019 cropping season (CSA, 2019). According to CSA (2019) data, it was also indicated that the distribution of papaya across the country was only $3.34 \%$ as compared to other fruit crops despite its importance. The productivity of papaya in the country is 14 tha $^{-1}$ (CSA, 2019) which is very low as compared to the world average yield (30 $\mathrm{t} \mathrm{ha}^{-1}$ ) (FAOSTAT, 2019). Southern Nations, Nationalities and Peoples' (SNNP) regional state shared 40,47 and $60 \%$ in number of smallholders, area coverage and total production of papaya, respectively as compared to the country (CSA, 2019). This indicates that the region has huge potential for papaya 
production. Arba Minch, the fruit paradise, is one of the districts found in SNNP regional state where different fruit crops are dominantly produced for income generation (Tuma, 2007). However, the total area covered by papaya and its productivity is very low as compared to the potential that the country and Arba Minch have.

Lack of improved papaya varieties and low accessibility of the existing improved varieties are among the major papaya production constraints in Arba Minch, in particular and in Ethiopia, in general. Therefore, this study was conducted to evaluate the adaptability of newly released papaya varieties at Arba Minch, Southern Ethiopia to increase the accessibility of available improved papaya varieties for growers.

\section{Materials and Methods}

\section{Descriptions of the study area}

This study was conducted at Chano Mille research site of Arba Minch Agricultural Research Center for two years (2019-2020). It is situated at $5^{\circ} 59^{\prime}$ to $6^{\circ} 4^{\prime} \mathrm{N}$ and $37^{\circ} 31^{\prime}$ to $37^{\circ} 36^{\prime} \mathrm{E}$ at an altitude of 1220 m.a.s.l. The site received mean annual rainfall of $713 \mathrm{~mm}$ with minimum and maximum temperature of 17 and $31^{\circ} \mathrm{C}$, respectively in the two consecutive years (20192020).

\section{Experimental treatments and design}

The three newly released papaya varieties namely; Braz-HS1 (CMFo78-L56), Koka-HM1 (KK103-L446) and Meki-HL1 (MK121-L516) were used for this study. Melkassa Agricultural Research Center (MARC) released these varieties in 2015 cropping season owing to their distinct characters such as fruit size, flesh aroma and color, fiber, skin thickness, pulp TSS ( ${ }^{\circ}$ Brix) and fruit yield (MoA, 2015). The experimental treatments were arranged in Randomized Complete Block Design in three replications. The seedlings of the three varieties were brought from MARC and planted at the spacing of $2.5 \mathrm{~m}$ between rows and plants in a plot size of $10 \mathrm{~m}_{\mathrm{x}}$ $7.5 \mathrm{~m}$. All other agronomic management practices (supplementary irrigation, weeding, etc.) were applied uniformly to all varieties as per the recommendation for the crop (MoA, 2015).

\section{Data collection and analysis}

Data were collected for six traits namely; fruit weight (FW), fruit diameter (FD), fruit length (FL), number of fruits plant ${ }^{-1}$ (NFP), number of leaves plant ${ }^{-1}(\mathrm{NL})$ and fruit yield throughout the years. All the collected data were subjected to analysis of variance by using the procedures outlined by Gomez and Gomez (1984) through SAS software version 9.2 (SAS, 2008). Mean separation was done by using Least Significant Difference (LSD) to compare significant treatment means at $5 \%$ level of significance.

\section{Results and Discussion}

The analysis of variance results revealed that all the traits considered in this study showed significant differences among the varieties (Table 1). Accordingly, the maximum number of fruits per plant and number of leavesplant ${ }^{-1}$ were observed in Braz-HS1 variety whereas Koka-HM1 and Meki-HL1 exhibited the least in the two traits without significant difference among each other. The highest fruit weight was obtained from MekiHL1 variety that is statistically similar with KokaHM1 variety while fruit weight of Braz-HS1 was significantly minimum (Table 2). The highest fruit yield was obtained from Braz-HS1 variety while the lowest fruit yield was harvested from Koka-HM1 variety. This might be due to the genetic difference of the variety that can show its performance in a given area. It was also reported that the inherent characters of the varieties, space availability, nutrient availability and weather condition of the specific area (MoA, 2015; Wegayehu et al., 2016; Ayele et al., 2017) influenced the performance of papaya varieties in terms of yield and yield components. The fruit yield of Braz-HS1 was more than six fold of the current papaya productivity in both the region and country. Therefore, production of Braz-HS1 papaya variety could increase the productivity of papaya in the study area if all appropriate agronomic practices were applied.

Table 1. Analysis of variance for the traits considered in this study.

\begin{tabular}{|c|c|c|c|c|c|c|c|}
\hline \multirow{2}{*}{$\begin{array}{l}\text { Source of } \\
\text { variation }\end{array}$} & \multirow{2}{*}{$\begin{array}{l}\text { Degrees } \\
\text { of } \\
\text { freedom }\end{array}$} & \multicolumn{6}{|c|}{ Mean Squares } \\
\hline & & NL & NFP & FW & FD & FL & Yield \\
\hline Variety & 2 & $133.58^{*}$ & $67.78^{*}$ & $44205 \cdot 34^{*}$ & $25.33^{*}$ & $8.087^{*}$ & $1825.18^{* * *}$ \\
\hline Replication & 3 & 7.60 & 42.49 & 13950.70 & 3.83 & 1.810 & 46.76 \\
\hline Error & 6 & 21.47 & 14.68 & 10652.90 & $5 \cdot 90$ & 1.640 & 46.77 \\
\hline Grand mean & & 32.58 & 28.33 & 411.23 & 21.42 & 17.080 & 67.97 \\
\hline $\mathrm{LSD}_{(0.05)}$ & & 8.02 & 6.63 & 178.58 & 4.20 & 2.210 & 11.83 \\
\hline CV (\%) & & 14.20 & 13.50 & 25.09 & 11.30 & $7 \cdot 500$ & 10.10 \\
\hline
\end{tabular}

FW: fruit weight; FD: fruit diameter; FL: fruit length; NFP: number of fruits plant ${ }^{-1}$; $N L$ : number of leaves plant ${ }^{-1}$. 
Table 2. Mean values of yield and yield components of the three papaya varieties evaluated at Arba Minch, Southern Ethiopia.

\begin{tabular}{|c|c|c|c|c|c|c|}
\hline \multirow[t]{2}{*}{ Varieties } & \multicolumn{6}{|c|}{ Parameters } \\
\hline & NL & NFP & FW (g) & $\mathrm{FD}(\mathrm{cm})$ & $\mathrm{FL}(\mathrm{cm})$ & Yield (t ha-1) \\
\hline Braz-HS1 (CMFo78-L56) & $39.25 a$ & $31.50 a$ & $401.94 \mathrm{~b}$ & $18.75 \mathrm{~b}$ & $15.50 \mathrm{ob}$ & $91.30 a$ \\
\hline Koka-HM1 (KK103-L446) & $29.50 \mathrm{ob}$ & $29.80 a b$ & $585.13 \mathrm{ab}$ & $23.65 \mathrm{a}$ & $18.25 \mathrm{a}$ & $49.31 \mathrm{c}$ \\
\hline Meki-HL1 (MK121-L516) & $29.50 b$ & $23.67 \mathrm{~b}$ & $711.63 a$ & $21.85 \mathrm{ab}$ & $17 \cdot 50 a b$ & $63.34 \mathrm{~b}$ \\
\hline $\mathrm{LSD}_{(0.05)}$ & 8.02 & 6.63 & 178.58 & 4.20 & 2.21 & 11.83 \\
\hline CV (\%) & 14.20 & 13.50 & 25.09 & 11.30 & 7.50 & 10.10 \\
\hline
\end{tabular}

FW: fruit weight; FD: fruit diameter; FL: fruit length; NFP: number of fruits plant ${ }^{-1}$; $N L$ : number of leaves plant ${ }^{-1}$.

Means in each column followed by the same letter(s) were not significantly different at 5\% significance level.

\section{Conclusion and Recommendation}

Papaya is one of the most economically important fruit crops grown in Gamo zone mainly by smallholder farmers. This study showed that there was significant variation among the papaya varieties evaluated at Arba Minch, Southern Ethiopia. Among the evaluated varieties, the highest fruit yield was obtained from Braz-HS1 variety as compared to other varieties. Therefore, this variety could be recommended for wider production in the study area and vicinity with similar agro-ecology.

\section{Acknowledgements}

The authors would like to thank the Ethiopian Institute of Agricultural Research for financial support for this study and Arba Minch Agricultural Research Center for facilitating the allocated budget timely. They also appreciate the support of Alemayehu Wodaje and other technical assistants who participated in data collection.

\section{References}

Ayele, L., Etissa,E., Dagnew, A., Assefa, W., Kebede, G., Girma, M., Firde, K. and Ayalew, M. 2017. Development of hermaphrodite papaya (Carica papaya L.) varieties for production in Ethiopia. Acad. Res. J. Agri. Sci. Res. 5(7): 561-569.

http://doi.org/10.14662/ARJASR2017.087

CSA (Central Statistical Agency of Ethiopia) 2019. Report on Area and Production of Major Crops. Agricultural Sample Survey. Volume I, Statistical Bulletin 589. Addis Ababa, Ethiopia. p.13.

FAOSTAT (Food and Agriculture Organization Corporate Statistical Database). 2019. World Papaya Production Status. Food and Agriculture Organization of the United Nations, Statistical Division. Available online at http://www.fao.org/faostat/en/\#d ata/QC/visualize. Accessed on May 4, 2021.

Gomez, K.A. and Gomez, A.A. 1984. Statistical Procedures for Agricultural Research. $2^{\text {nd }}$ Edn. John Wiley and Sons, New York. 68op.

Josef, S.B. 2008. Production of papaya: A production manual, Provide in support of papaya extension program of the Ministry of Agriculture Land and Marine Resources, extension, training and information division, Trinidad and Tobago. pp. 1-18.
Mello, V.J., Gomes, M.T.R., Lemos, F.O., Delfino, J.L., Andrade, S.P., Lopes, M.T.P. and Salas, C.E. 2008. The gastric ulcer protective and healing role of cysteine proteinases from Carica candamarcensis. Phytomed. 15(4): 237-244.

https://doi.org/10.1016/j.phymed.2007.06.004

Milind, P. and Gurditta, G. 2017. Basketful benefits of Papaya. Int. Res. J. Pharma. 2: 6-12.

Ming, R., Hou, S., Feng, Y., Yu, Q., DionneLaporte, A., et al. 2008. The draft genome of the transgenic tropical fruit tree papaya (Carica papaya Linnaeus). Nature. 452: 991-996. https://doi.org/10.1038/natureo6856

MoA (Ministry of Agriculture). 2015. Plant Variety Release, Protection and Seed Quality Control Directorate. Crop variety register: Ministry of Agriculture, Addis Ababa, Ethiopia. Issue No. 16, 318p.

Munoz, V., Sauvain, M., Bourdy, G., Callapa, J., Rojas, I., Vargas, L., Tae, A. and Deharo, E. 2000. The search for natural bioactive compounds through a multidisciplinary approach in Bolivia. Part II. Antimalarial activity of some plants used by Mosetene Indians. J. Ethnopharmacol. 69(2): 139-155. https://doi.org/10.1016/So378-8741(99)00096-3

SAS (Statistical Analysis of Software) Institute Inc. Cary. 2008. User's Guide. Version 9.2. NC. USA. pp. 413-431.

Sepiah, M. 1993. Efficacy of propiconazole against fungi causing postharvest on Eksotica papaya. pp. 53. In: Proceedings of the International Postharvest Conference on Handling Tropical Fruits (Chiangnai), Thailand.

Serrano L.A.L. and Cattaneo, L.F. 2010 The cultivation of papaya in Brazil. Rev. Bras. Fruit. 32(03): 657-959.

https://doi.org/10.1590/So100-29452010000300001

Tuma, A. 2007. Effect of fruit based land use systems on soil physicochemical properties: the case of smallholders farming systems in Gamo Gofa, Southern Ethiopia. MSc thesis, Hawassa University, Hawassa, Ethiopia. 115p.

Wegayehu, A., Lemma, A., Asmare, D., Edossa, E., Girma, K., Mikiyas, D. and Merkebu, A. 2016. Variability, association and path coefficient analysis of yield and yield components of dioecious papaya genotypes in Ethiopia. Int. J. Res. Agric. Forest. 3(10): 8-14. 